\title{
Tuition ANd Outcomes For BRC Versus Non-BRC SchOols: An EMPIRICAL ANALYsis
}

\author{
Michael 7. Gallagher
}

Michael J. Gallagher (mgallagh@sbu.edu) is Assistant Professor at St. Bonaventure University; 3261 West State Road, St. Bonaventure, NY 14778. Correspondence concerning this paper should be addressed to Michael Gallagher.

\begin{abstract}
This paper is an empirical analysis of the rise in tuition costs across the United States. Schools of the Business Research Consortium of Western New York are compared to similar universities and national averages. In nominal terms, tuition costs have skyrocketed since 1970. The price tag associated with higher education is staggering. This study looks at the change in real cost of college over the last fifty years. The study compares the change in starting salaries for college graduates and the increase in tuition costs. Next the study compares net costs of tuition across the Business Research Consortium with similar schools across different regions of the United States. Actual net costs of tuition are compared across time. How will the Excelsior program affect the college landscape? Is Western New York indicative of the general population? These questions are explored; perhaps the preponderance of affordable
\end{abstract}


online education will become the new norm. This paper attempts to unravel issues surrounding the high cost of tuition.

Keywords: Tuition, Higher Education Costs

Data Availability: Data used in this study are available from public sources.

DOI: http://dx.doi.org/10.15239/j.brcadvjb.2018.03.01.ja01

\section{INTRODUCTION}

Tuition costs have skyrocketed over the last fifty years. Yet, more and more students year after year are attending college. Years ago, what was a privilege reserved for society's elite is today considered almost a rite of passage for the average young adult. Today's college students are paying more and more money to attend school; most are motivated by the opportunity to earn higher salaries and a more comfortable lifestyle in the future. This paper seeks to explore the questions, do higher and higher costs associated with attending college result in commensurate increases in earning potential, and how much is the actual costs to be educated after institutions issue grants and tuition aid?

There are many complicated reasons for incurring significant debt to attend a high priced university. The traditional motivation, expand horizons and the pursuit of knowledge, still a driving force predominately among the elitist demography. However, more pragmatic are the vast numbers of so-called middle class; a college education does widen prospects for getting a good well-paying job. Indeed, many students today simply want the "college experience," mostly attributable to the peer pressure associated with attending college. It would be unusual indeed in this day and age to hear a high school student proudly announce their intention to become a welder, when their peers are all scrambling to write college entrance essays. Even if the student would be better suited training as a tradesman, and clearly would be happier, peer pressure 
and lack of life experience would dictate they follow the others, perhaps starting tentatively at a community college.

Many students incur significant debt to fulfill the college dream, now considered a "rite of passage." This prompts us to consider the agency relationship of the student loan industry.

Without a doubt, student loans have skyrocketed, prompting the government to intervene. The government on one hand wants to be helpful by incorporating a means payment plan. If you do not have the income, you can repay your student loans according to your means. On the other hand, the government has also incorporated a plan where they garnish social security payments to individuals who have consistently neglected to service their student loan debt. The idea that an individual stills owes on student loan debt at retirement age is incomprehensible. In this extreme case, it would seem the education as an investment was a poor choice.

The ubiquitous desire to attend college has spawned a savvier consumer. Educated and intelligent parents know the challenges associated with translating a high priced education into a lucrative career. The solution relies on universities staying cutting edge. Universities understand the market; the product being delivered is the latest and greatest.

Indeed, does this level of market maturity contribute to the problem? Part of the indication that a university is delivering a quality product is the price tag. Price signals to society the product is superior. Would it be heresy to suggest that even if the product was not superior, the high price, and the reputation, creates the illusion that the graduate is the smartest in the room? Not only that, but the high price tag may be simply a marketing ploy, some high sticker prices are subsequently so heavily discounted the nominal tuition is an illusion of outstanding quality, when in fact the actual cost is much more affordable. 


\section{Average Tuition and Salaries across the United STATES}

Tuition rates have grown dramatically over the years, and the number of students has grown. Evidence shows however, the starting salary for recent college graduates is not any different than it was fifty years ago.

First in this analysis is the average total cost of attending a public institution across the United States. In 1965, tuition for in-state public institutions was $\$ 243$. This includes four year colleges, four year universities, other four year institutions, and two -year institutions, in nominal terms. At these institutions, a dormitory was $\$ 271$, and board was $\$ 436$, so a total yearly college experience was $\$ 950$. In 2006, tuition for this same group was $\$ 4,101$. A dormitory was $\$ 3,747$, and board was $\$ 3,185$, so a total yearly college experience was $\$ 11,034 .^{1}$

The average starting salary for a bachelor's degree graduate in 1965 was $\$ 7,257$. In 2006, a bachelor's degree job market candidate could expect to earn $\$ 43,321 .^{2}$

Tuition from 1965 to 2007 has increased $1065 \%$ in nominal terms. However, the starting salary has increased only 530\%. See Appendix: C, Figure 1. A cursory glance shows salary increasing with increases in tuition. A simple regression of nominal salary on nominal tuition over this time period reveals the slope of a line fitted to the data to be 3.8422 .

This is all in nominal terms; if tuition and salary are adjusted for inflation, a different picture emerges. Using the Bureau of Labor Statistics Consumer Price Index for $2016^{3}$ the adjusted percentage changes in tuition and starting salary tell a different story. Inflation adjusted tuition, room and board in 1965 is $\$ 7,238$, and inflation adjusted starting salary is $\$ 52,994$. Inflation adjusted tuition, room and board in 2006 is $\$ 12,774$, and inflation adjusted starting salary in 2006 is $\$ 52,046$. In real terms, tuition has increased much less, only $74 \%$ while starting salaries for new college graduates is actually down about $2 \%$. See Figure 2. Clearly in 
real terms, increases in college costs have rampantly outpaced increases in starting salaries.

A simple regression of real salary on real tuition over this time period reveals the slope of a line fitted to the data to be -0.5906 .

There is a similar rise among private institutions. Figure 3 shows an unadjusted significant rise in starting salaries accompanying tuition increases since 1965. Average tuition at private institutions in 1965 was $\$ 1,088$. This includes four year colleges, four year universities, other four year institutions, and two year institutions, in nominal terms. At these institutions, a dormitory was $\$ 331$, and board was $\$ 488$, so a total yearly college experience was $\$ 1,907$. In 2006 , tuition for this same group was $\$ 19,991$. A dormitory was $\$ 4,607$, and board was $\$ 3,787$, so a total yearly college experience was $\$ 28,348$. In fact we see a $1388 \%$ increase in tuition among private schools.

However, again, when the inflation adjusted comparison is made, as in Figure 4, real average total cost of private institutions in 1965 was $\$ 14,529$, a $126 \%$ increase, and of course no change in starting salary.

A simple regression of real salary on real tuition over this time period reveals the slope of a line fitted to the data to be -0.0240 . In other words, for every dollar increase in tuition, actually starting salary decreases by $\$ 0.02$. There were slightly better prospects for a private educated individual. Perhaps the enormous growth in enrolments at public institutions over this period contributed to the difference.

This study has so far only looked at averages across all majors across the United States. There is a generally held belief that business schools have less of a problem maintaining or growing enrolments than have colleges of arts and sciences. Figure 5, looks at accounting majors over the years from 1965 to 2007 in real terms. There is again virtually no change in the inflation adjusted starting salaries of accounting majors while tuition has steadily increased. 
Lastly, we look at the humanities, to round out our exploration of average United States Tuition vs. Starting Salaries. Again as tuition rises steadily over the years from 1965 to 2007, starting salaries have not budged in inflation adjusted terms. See Figure 6.

This analysis has considered nationwide averages and has naively ignored the effects of financial aid, subsidies, and loans. In the following sections, schools of the Western New York BRC are considered from a perspective of sticker price and actual net price to attend, then seven schools of the BRC are compared to seven comparable schools in each of four distinct geographic regions across the United States.

\section{Preview Complete}

This completes the limited preview of this paper. Please visit the link below to purchase.

\section{Citation Information}

Gallagher, Michael, J. "Tuition and Outcomes for BRC Versus Non-BRC Schools: An Empirical Analysis.” BRC Journal of Advances in Business 3, no. 1 (2018): 1 -14. http://dx.doi.org/10.15239/j.brcadvjb.2018.03.01.ja01

\section{Web APPEndix}

A web appendix for this paper is available at: http://dx.doi.org/10.15239/ j.brcadvjb.2018.03.01.wa01 